\title{
(c) $(0$
}

Ryszard Mikosz

(D) http://orcid.org/0000-0002-6588-1000

Uniwersytet Śląski w Katowicach

\section{Własność kopalin i własność wód - kilka uwag o konstrukcji prawnej*}

1. Nie ulega najmniejszej wątpliwości, że zarówno kopaliny, jak i wody to dobra materialne, których znaczenia niepodobna przecenić. Nie tylko bowiem są one elementami środowiska ${ }^{1}$ warunkującymi byt organizmów żywych, ale także spełniają istotną rolę w działalności gospodarczej. Oczywiste jest zatem, że ustawodawca dążyć powinien do optymalnego ukształtowania ich statusu prawnego, uwzględniając z jednej strony konieczność korzystania z nich w niezbędnym zakresie, z drugiej natomiast potrzebę wyznaczenia ram tego korzystania w sposób umożliwiający efektywną ochronę tych dóbr.

2. Status prawny kopalin i wód kształtuje spora ilość przepisów, rozproszonych w wielu fragmentach systemu prawa. W tym stanie rzeczy całościowa analiza tych przepisów znacznie wykraczałaby poza założone ramy opracowania, zwłaszcza gdy zważyć, że wiele z nich skonstruowanych zostało w sposób bardzo kazuistyczny, co jest niestety manierą współczesnego ustawodawcy. Dlatego też w toku dalszych uwag zaprezentowana zostanie wyłącznie garść refleksji odnoszących się do jednej z fundamentalnych kwestii, jaka powinna być uwzględniana przy rozważaniu statusu prawnego każdego w istocie dobra.

* Stan prawny na dzień 31 października 2019 r.

${ }^{1}$ Zgodnie z definicją środowiska zawartą w art. 3 pkt 39 ustawy z dnia 27 kwietnia $2001 \mathrm{r}$. Prawo ochrony środowiska (t.j. Dz.U. 2019, poz. 1396 ze zm.) rozumie się przez nie ogół elementów przyrodniczych, w tym także przekształconych w wyniku działalności człowieka, a w szczególności powierzchnię ziemi, kopaliny, wody, powietrze, krajobraz, klimat oraz pozostałe elementy różnorodności biologicznej, a także wzajemne oddziaływania pomiędzy tymi elementami. 
Chodzi mianowicie o regulację dotyczącą własności kopalin oraz wód. Do podjęcia takiej refleksji skłania w pierwszej kolejności niedawna zasadnicza zmiana stanu prawnego w zakresie dotyczącym gospodarowania wodami, będąca wynikiem wprowadzenia do obrotu prawnego ustawy z dnia 20 lipca 2017 r. - Prawo wodne ${ }^{2}$. Nie można jednak również tracić z pola widzenia faktu, że okres, jaki upłynął od wejścia w życie ustawy z dnia 9 czerwca 2011 r. - Prawo geologiczne i górnicze ${ }^{3}$ jest także stosunkowo krótki, a aktem tym wprowadzono diametralnie odmienną od dotychczasowej konstrukcję prawną dotyczącą własności najważniejszych złóż kopalin. Chodzi mianowicie o instytucję własności górniczej, nieznaną wcześniej obowiązującej ustawie z dnia 27 lutego 1994 r. Prawo geologiczne i górnicze ${ }^{4}$, na której skoncentrować wypadnie uwagi dotyczące własności złóż kopalin. Regulacja dotycząca własności kopalin oraz wód zawarta $\mathrm{w}$ obydwu wspomnianych aktach budzi liczne wątpliwości, które po wejściu w życie Prawa wodnego jeszcze uległy pomnożeniu. Na niektóre z nich wypadnie zwrócić uwagę w ramach dalszych rozważań.

3. Wątpliwości te zaczynają się już przy próbie odpowiedzi na pytanie o to, czy kopaliny i wody są rzeczami w rozumieniu prawa cywilnego. Zdecydowana większość doktryny, a także szczupłe w sumie orzecznictwo, wyraża pogląd, że odpowiedź ta powinna być negatywna ${ }^{5}$. Zapatrywanie to jest jednak, jak się wydaje, na ogół wyrażane dość mechanicznie i pozbawione przekonującego uzasadnienia. Kluczowy argument, który jest przywoływany na rzecz tej tezy, wskazuje na brak „samoistności” kopalin i wód będącej niezbędną cechą kwalifikującą rzecz. Skłania to do pytania o podstawę prawną mającą uzasadnić taki pogląd. W tym kontekście przypomnieć trzeba, że swego rodzaju definicja rzeczy zawarta $w$ art. 45 Kodeksu cywilnego ${ }^{6}$ jest mocno zwięzła, by nie rzec lapidarna. Stosownie bowiem do jego treści, rzeczami w rozumieniu tego kodeksu są tylko przedmioty materialne. „Materialność” zarówno wód, jak i kopalin jest oczywista. Jest to zaś jedyna cecha kwalifikująca rzecz w świetle art. 45 k.c. Dodać trzeba przy tym, że wymóg spełnienia przez rzecz cechy „samoistności” wprost nie wynika także z żadnego innego przepisu Kodeksu. Nie jest też dostatecznie jasne, jak wspomnianą „samoistność” należy rozumieć, nie sposób jednak ujmować jej wyłącznie w kategoriach samoistności „fizycznej”, chociażby mając na uwadze fakt, że nieruchomość gruntowa, będąca jedną

2 T.j. Dz.U. 2020, poz. 310 ze zm., dalej: pr.wodn.

3 T.j. Dz.U. 2020, poz. 1064 ze zm., dalej: pr.g.g.

${ }^{4}$ Dz.U. 2005, nr 228, poz. 1947 ze zm. Por. R. Mikosz: Własność górnicza - ewolucja stanu prawnego. W: Rozważania o... Red. G. Dobrowolski i in. Katowice 2018, s. 237 i nast.

${ }^{5}$ Por. szerzej na ten temat R. Mikosz. W: System Prawa Prywatnego. T. 3: Prawo rzeczowe. Red. E. GnieweK. Wyd. 4. Warszawa 2020, s. 190-192 oraz przywołaną tam literaturę.

${ }^{6}$ Ustawa z dnia 23 kwietnia 1964 r. — Kodeks cywilny (t.j. Dz.U. 2019, poz. 1145 ze zm.), dalej: k.c. 
z podstawowych kategorii rzeczy w obrocie, z natury nie jest „samoistna”. Przyjąć trzeba zatem, że o „samoistności” nie decydują cechy fizyczne rzeczy, lecz jest ona cechą normatywną, a o tym, czy mamy z nią do czynienia, decyduje ustawodawca?

4. Sygnalizowany wyżej problem ma bardzo istotne znaczenie w przypadku kopalin i wód, albowiem zarówno w Prawie geologicznym i górniczym, jak i w Prawie wodnym ustawodawca wielokroć posłużył się terminem „własność”, który ma swoje ustalone znaczenie w systemie prawa. Uznanie, że wspomniane dobra nie mają charakteru rzeczy, prowadzić musi zatem do stwierdzenia, że własność przysługująca w stosunku do nich nie jest własnością rzeczy, o której mowa w Kodeksie cywilnym. Do zagadnienia tego wypadnie jeszcze niejednokrotnie powracać w toku dalszych uwag.

5. Analiza statusu własnościowego każdego w istocie dobra wymaga, jak się wydaje, rozważenia kilku podstawowych kwestii cząstkowych. Odnosi się to zwłaszcza do odpowiedzi na pytania dotyczące: przedmiotu prawa (obiektu prawa ${ }^{8}$, podmiotu uprawnionego (podmiotów uprawnionych), treści prawa oraz środków służących jego ochronie. W tej też kolejności prowadzona będzie dalsza analiza.

6. Rozpoczynając rozważania dotyczące własności kopalin, należy w punkcie wyjścia dokonać niezbędnej systematyki zagadnienia. W tym zaś zakresie odnotować trzeba, że kopaliny mogą być objęte zarówno własnością górniczą, jak i własnością gruntową. Kopaliny będące przedmiotem własności górniczej wymienione zostały przede wszystkim $\mathrm{w}$ art. 10 ust. 1 pr.g.g., z którego wynika, że są to złoża węglowodorów ${ }^{9}$, węgla kamiennego, metanu występującego jako kopalina towarzysząca, węgla brunatnego, rud metali z wyjątkiem darniowych rud żelaza, metali w stanie rodzimym, rud pierwiastków promieniotwórczych,

${ }^{7}$ I tak np. zgodnie z regułą wynikającą z art. 48 k.c., z zastrzeżeniem wyjątków w ustawie przewidzianych, do części składowych gruntu należą w szczególności budynki i inne urządzenia trwale z gruntem związane, jak również drzewa i inne rośliny od chwili zasadzenia lub zasiania. Budynki są zatem - co do zasady - częściami składowymi rzeczy, nie mają więc charakteru dobra samoistnego. Czasem jednak - z woli ustawodawcy - traktowane są jako odrębne rzeczy (por. np. art. 235 i 272 k.c.).

${ }^{8}$ W literaturze można także napotkać poglądy, że przedmiotem prawa jest dozwolone zachowanie się uprawnionego, natomiast przedmiot, którego zachowanie to dotyczy, jest czasem nazywany „obiektem” prawa (por. w szczególności A. KLEIN: Elementy stosunku prawnego prawa rzeczowego. Wrocław 1976, s. 12; W. PAŃKo: Własność gruntowa w planowej gospodarce przestrzennej. Katowice 1978, s. 49).

${ }^{9}$ Zgodnie z definicją legalną zawartą w art. 6 ust. 1 pkt 16 pr.g.g. węglowodorami są ropa naftowa, gaz ziemny oraz ich naturalne pochodne, a także metan występujący w złożach węgla kamiennego, z wyjątkiem metanu występującego jako kopalina towarzysząca. 
siarki rodzimej, soli kamiennej, soli potasowej, soli potasowo-magnezowej, gipsu i anhydrytu, kamieni szlachetnych, bez względu na miejsce ich występowania. Własnością górniczą objęte zostały także złoża wód leczniczych, wód termalnych i solanek (art. 10 ust. 2 pr.g.g.), które to wody w świetle ustawy Prawo geologiczne i górnicze są kopalinami ${ }^{10}$.

7. Przedmiotem własności górniczej są także części górotworu położone poza granicami przestrzennymi nieruchomości gruntowej, w szczególności znajdujące się w granicach obszarów morskich Rzeczypospolitej Polskiej ${ }^{11}$ (art. 10 ust. 4 pr.g.g.). W przepisach ustawy Prawo geologiczne i górnicze wielokrotnie posłużono się pojęciem „górotwór”, nie zostało ono jednak bliżej dookreślone. Zgodnie zatem z powszechnie przyjętymi regułami wykładni prawa należy w takim przypadku sięgnąć do powszechnego znaczenia tego terminu. Jest ono zaś dwojakie - w naukach geologicznych rozumie się go bowiem jako „obszar sfałdowany i wypiętrzony w wyniku ruchów skorupy ziemskiej; orogen", w naukach górniczych górotwór oznacza natomiast „utwory skalne skorupy ziemskiej (zespół skał), w których prowadzone są roboty górnicze"12. Nie ulega wątpliwości, że tak pojmowany górotwór obejmuje także złoża wielu kopalin.

8. W sumie zatem przedmiot własności górniczej obejmuje dwie kategorie dóbr: złoża kopalin enumeratywnie wymienionych w art. 10 ust. 1 i 2 pr.g.g. oraz „górotwór”, czyli przestrzeń położoną poniżej dolnej granicy nieruchomości gruntowej ${ }^{13}$. Ten w miarę klarowny generalny obraz zagadnienia komplikuje się mocno, kiedy przychodzi przejść do szczegółów, co jest między innymi następstwem niezwykle nieprecyzyjnej definicji złoża zawartej w art. 6 ust. 1 pkt 19 pr.g.g. ${ }^{14}$, który to wątek trzeba jednak pominąć w dalszych rozważa-

${ }^{10}$ Stosownie bowiem do treści art. 5 ust. 1 pr.g.g. kopalinami nie są wody, z wyjątkiem wód leczniczych, wód termalnych i solanek. Definicje tych wód zamieszczone zostały w art. 5 ust. $2-4$ pr.g.g.

${ }^{11}$ Zgodnie z treścią art. 2 ust. 1 ustawy z dnia 21 marca 1991 r. o obszarach morskich Rzeczypospolitej Polskiej i administracji morskiej (t.j. Dz.U. 2019, poz. 2169 ze zm.), obszarami morskimi Rzeczypospolitej Polskiej są: morskie wody wewnętrzne, morze terytorialne, strefa przyległa, oraz wyłączna strefa ekonomiczna.

12 Stownik języka polskiego. Red. M. Szymczak. T. 1. Warszawa 1978, s. 688. Wydaje się, że w ustawie Prawo geologiczne i górnicze użyto tego terminu w znaczeniu bliższym naukom górniczym, o czym świadczy chociażby definicja wyrobiska górniczego zawarta w art. 6 ust. 1 pkt 17 ustawy.

13 Trzeba bowiem pamiętać, że przestrzeń nieruchomości gruntowej jest ograniczona, co wprost wynika ze zdania pierwszego art. 143 k.c. stanowiącego, że w granicach określonych przez społeczno-gospodarcze przeznaczenie gruntu własność gruntu rozciąga się na przestrzeń nad i pod jego powierzchnią. Szerzej na ten temat por. R. Mikosz. W: System Prawa Prywatnego. T. 3: Prawo rzeczowe... s. 101 i nast. oraz wskazane tam literaturę i orzecznictwo.

${ }^{14}$ Stosownie do treści tego przepisu złożem kopaliny jest naturalne nagromadzenie minerałów, skał oraz innych substancji, których wydobywanie może przynieść korzyść gospodarczą. 
niach. Odnotowania wymaga natomiast regulacja zawarta w art. 10 ust. 3 pr.g.g., z której wynika, że złoża kopalin niewymienionych w art. 10 ust. 1 i 2 (a więc nie będące przedmiotem własności górniczej) są objęte prawem własności nieruchomości gruntowej. Brzmienie tego przepisu nie pozostawia wątpliwości, że w odniesieniu do tej grupy kopalin ustawodawca pozostawił dotychczasową konstrukcję prawną i wspomniane złoża stanowią części składowe nieruchomości gruntowej, dzieląc jej los prawny, na co wskazuje zwłaszcza użyty w nim zwrot „są objęte”. Tę grupę kopalin można pominąć w toku dalszych rozważań, albowiem regulacja ich dotycząca w niczym nie odbiega od unormowań odnoszących się do własności rzeczy zawartych w Kodeksie cywilnym.

9. Ustalenie przedmiotu prawa własności wód nastręcza nieco więcej trudności, będących konsekwencją złożoności regulacji zawartej w ustawie Prawo wodne. $Z$ jej art. 2 ust. 1 wynika, że reguluje ona między innymi „sprawy własności wód". Treść tego przepisu mogłaby zatem prowadzić do wniosku, że chodzi o wszystkie wody objęte przepisami tego aktu, co jednak o tyle byłoby konkluzją błędną, że zakres zastosowania ustawy do poszczególnych rodzajów wód jest zróżnicowany. Generalna reguła w tym względzie wyrażona została w art. 3 pr.wodn., z którego wynika, że przepisy ustawy stosuje się do wód śródlądowych oraz morskich wód wewnętrznych. $\mathrm{Z}$ treści art. 19 pr.wodn. płynie wiosek, że wodami śródlądowymi są wszystkie wody, z wyłączeniem morskich wód wewnętrznych i wód morza terytorialnego. Morskie wody wewnętrzne określone zostały natomiast $\mathrm{w}$ art. 4 przywołanej już ustawy o obszarach morskich Rzeczypospolitej Polskiej i administracji morskiej, w której sięgnięto głównie do kryterium geograficznego. Szczegóły w tym zakresie trzeba jednak pominąć. Odnotować trzeba natomiast, że zgodnie z art. 4 pr.wodn., przepisy ustawy stosuje się do wód morza terytorialnego w zakresie planowania w gospodarowaniu wodami, ochrony przed zanieczyszczeniem ze źródeł lądowych oraz ochrony przed powodzią, a w pozostałym zakresie - w przypadkach określonych $\mathrm{w}$ ustawie ${ }^{15}$. W myśl z kolei art. 5 pr.wodn., przepisy ustawy stosuje się do wyłącznej strefy ekonomicznej Rzeczypospolitej Polskiej w przypadkach określonych w ustawie.

10. Sygnalizowane dotychczas wątpliwości ulegają pomnożeniu, jeśli sięgnąć do regulacji zawartej w rozdziale 1 działu 6 Prawa wodnego, zatytułowa-

Szerzej na ten temat por. A. LiPIŃsKi: Komentarz do art. 6-9 ustawy z dnia 9 czerwca 2011 r. Prawo geologiczne i górnicze. „Problemy Prawne Górnictwa i Ochrony Środowiska” 2017, nr 1, s. 24 oraz (pod rządem poprzedniego stanu prawnego); A. Lipiński, R. Mikosz: Prawo geologiczne i górnicze. Komentarz. Warszawa 2003, s. 42-43. Por. także A. LipiŃski: Prawne podstawy geologii $i$ górnictwa. Warszawa 2019, s. 30-31 oraz s. 40 i nast.; P. WoJtulek, T. Kocowski, W. MaŁecki: Prawo geologiczne i górnicze. Warszawa 2020, s. 51 i nast.

${ }_{15}$ Por. np. art. 32 ust. 1 i 34 pkt 8 pr.wodn. 
nym „Własność wód i obowiązki ich właścicieli”. Z treści art. 211 ust. 2 pr.wodn. wynika bowiem, że uregulowana została w nim kwestia własności wód morza terytorialnego, morskich wód wewnętrznych, śródlądowych wód płynących ${ }^{16}$ oraz wód podziemnych ${ }^{17}$. Nietrudno dostrzec zatem, że przepis ten nie dotyczy śródlądowych wód stojących. Materię tę reguluje natomiast, aczkolwiek w sposób pozostawiający wiele do życzenia, art. 214 pr.wodn., w którym określony został status własnościowy „śródlądowych wód stojących, wód w rowach oraz wody w stawie, który nie jest napełniany w ramach usług wodnych, ale wyłącznie wodami opadowymi lub roztopowymi lub wodami gruntowymi".

11. Definicja „rowów” zamieszczona została w art. 16 pkt 47 pr.wodn., w myśl którego są to „sztuczne koryta prowadzące wodę w sposób ciągły lub okresowy, o szerokości dna mniejszej niż 1,5 m przy ujściu". Skoro więc chodzi o ,prowadzenie wód”, to wydaje się, że woda w nich jest (a przynajmniej może być) powierzchniową wodą płynącą. Są to zatem powierzchniowe wody płynące, a regulację zawartą w art. 214 pr.wodn. uznać trzeba za szczególną wobec zasady wynikającej z art. 211 ust. 2 pr.wodn. Dużo bardziej złożonym zabiegiem jest ustalenie znaczenia zwrotu „wody w stawie, który nie jest napełniany w ramach usług wodnych, ale wyłącznie wodami opadowymi lub roztopowymi lub wodami gruntowymi". W tym zakresie, w punkcie wyjścia odnotować trzeba, że z art. 16 pkt 65 lit. c. pr.wodn. wynika, że staw jest rodzajem „urządzenia wodnego”. Akwen jest jednak „stawem” w rozumieniu Prawa wodnego jedynie wówczas, gdy służy do „kształtowania zasobów wodnych” lub „korzystania z tych zasobów"18. Wszystkie inne akweny nie są zatem stawami, ale powierzchniowymi wodami stojącymi. Rozgraniczenie rodzajów takich akwenów może napotykać jednak na spore trudności już chociażby wobec faktu, że zwrot „kształtowanie zasobów wodnych" trudno uznać za precyzyjny ${ }^{19}$. Szczegóły w tym zakresie trzeba jednak pominąć.

${ }^{16}$ Stosownie do treści art. 22 pr.wodn. śródlądowymi wodami płynącymi są wody w: ciekach naturalnych oraz źródłach, z których te cieki biorą początek, jeziorach oraz innych naturalnych zbiornikach wodnych o ciągłym albo okresowym naturalnym dopływie lub odpływie wód powierzchniowych, sztucznych zbiornikach wodnych usytuowanych na wodach płynących, a także kanałach.

${ }_{17}$ Przez „wody podziemne” rozumie się wszystkie wody znajdujące się pod powierzchnią ziemi w strefie nasycenia, w tym wody gruntowe pozostające w bezpośredniej styczności z gruntem lub podglebiem (art. 16 pkt 48 pr.wodn.).

${ }^{18}$ Zgodnie z brzmieniem art. 16 pkt 65 in fine przez urządzenia wodne rozumie się urządzenia lub budowle służące do kształtowania zasobów wodnych lub korzystania z tych zasobów. $\mathrm{W}$ dalszej części tego przepisu enumeratywnie wymieniono te urządzenia, wliczając $\mathrm{w}$ ich zakres m.in. stawy.

${ }^{19}$ Na marginesie tylko odnotować trzeba, że zgodnie z art. 23 ust. 2 pr.wodn. przepisy o śródlądowych wodach stojących stosuje się odpowiednio do wód znajdujących się w zagłębieniach terenu powstałych w wyniku działalności człowieka, niebędących stawami. 
12. Dalszą, wymagającą sygnalizowania kwestią jest to, że przepis art. 214 pr.wodn. odnosi się jedynie do stawów ,nie napełnianych w ramach usług wodnych”. Kluczowe znaczenie w ramach tego zwrotu wydaje się mieć słowo „napełniane", które powinno być skonfrontowane z treścią art. 35 ust. 3 pr.wodn. określającego listę zachowań składających się na usługi wodne ${ }^{20}$. Analiza tych zachowań prowadzi do wniosku, że w istocie rzeczy trudno w ich ramach wskazać takie, które polegać mogłoby na wspomnianym „napełnianiu”. Problem ten wymaga jednak odrębnej analizy.

13. Kolejnym zagadnieniem wymagającym rozważenia jest ustalenie podmiotu uprawnionego (podmiotów uprawnionych), któremu przysługiwać może własność kopalin i wód. W przypadku własności górniczej zagadnienie to jawi się stosunkowo klarownie, albowiem podmiotem tym jest wyłącznie Skarb Państwa, co wprost wynika z art. 10 ust. 5 pr.g.g. Inaczej problem ten kształtuje się natomiast na gruncie Prawa wodnego. Co prawda właścicielem zdecydowanej większości wód jest Skarb Państwa, jednak są również wody, które mogą być własnością innych podmiotów. Spostrzeżenie to potwierdza treść art. 211 ust. 1 pr.wodn., z którego wynika, że wody stanowią własność Skarbu Państwa, innych osób prawnych albo osób fizycznych. Przywołany już wyżej art. 211 ust. 2 pr.wodn. przesądza, że własnością Skarbu Państwa są wody morza terytorialnego, morskie wody wewnętrzne, śródlądowe wody płynące oraz wody podziemne. $Z$ kolei w myśl również już wskazanego art. 214 pr.wodn. śródlądowe wody stojące, woda $\mathrm{w}$ rowie oraz woda $\mathrm{w}$ stawie, który nie jest napełniany w ramach usług wodnych, ale wyłącznie wodami opadowymi lub roztopowymi lub wodami gruntowymi, znajdujące się w granicach nieruchomości gruntowej stanowią własność właściciela tej nieruchomości. Kryterium, za pomocą którego wskazany został właściciel wód, jest zatem generalnie rodzaj wód. O ile jednak w odniesieniu do rodzajów wód wymienionych w art. 211 ust. 2 pr.wodn. właścicielem może być wyłącznie Skarb Państwa, o tyle własność wód wymienionych $\mathrm{w}$ art. 214 pr.wodn. może przysługiwać różnym podmiotom. Ich właścicielem jest bowiem właściciel gruntu, na którym znajdują się wody powierzchniowe określone w tym przepisie. Nie ulega zatem wątpliwości, że w kręgu tych podmiotów znajduje się również Skarb Państwa, jednak jego identyfikacja następuje w inny sposób, aniżeli ma to miejsce w świetle unormowania zawartego w art. 212 pr.wodn.

14. W przypadku kiedy właścicielem określonego dobra jest Skarb Państwa, istotną kwestię stanowi zawsze problem wykonywania uprawnień właścicielskich ze względu na specyfikę tej osoby prawnej. W ustawie Prawo geologiczne i górnicze regulacja dotycząca wykonywania uprawnień w odniesieniu do włas-

${ }^{20}$ Do problematyki usług wodnych wypadnie powrócić w dalszej części rozważań. 
ności górniczej jest stosunkowo prosta. W art. 12 ust. 2 pr.g.g. wyodrębnione zostały w tym zakresie dwie różne sytuacje prawne, inaczej kształtuje się bowiem wykonywanie uprawnień w odniesieniu do działalności, która wymaga koncesji, inaczej natomiast $\mathrm{w}$ odniesieniu do pozostałej regulowanej Prawem geologicznym i górniczym. W pierwszej z tych sytuacji uprawnienia Skarbu Państwa w zakresie wynikającym z własności górniczej wykonują właściwe organy koncesyjne ${ }^{21}$, w drugim natomiast zarządy województw²2. Dużo bardziej skomplikowana jest natomiast regulacja dotycząca reprezentacji Skarbu Państwa w przypadku wykonywania uprawnień płynących z własności wód. W tym zakresie już w punkcie wyjścia wyodrębnić można dwojakiego rodzaju przypadki. Inaczej wygląda bowiem kwestia reprezentacji Skarbu Państwa w odniesieniu do wód, o których mowa w art. 212 ust. 2 pr.wodn., inaczej natomiast w stosunku do wód wymienionych w art. 214 pr.wodn. W pierwszym z tych przypadków prawa właścicielskie odnoszące się do wód publicznych ${ }^{23}$ stanowiących własność Skarbu Państwa wykonują albo Wody Polskie ${ }^{24}$ (w odniesieniu do śródlądowych wód płynących oraz wód podziemnych, z wyłączeniem śródlądowych dróg wodnych o szczególnym znaczeniu transportowym ${ }^{25}$ ), albo minister właściwy do spraw gospodarki morskiej ${ }^{26}$ (w stosunku do wód morza terytorialnego oraz

${ }^{21}$ Organami koncesyjnymi są Minister Środowiska, marszałek województwa oraz starosta. Właściwość każdego z tych organów określa regulacja zawarta w art. 22 pr.g.g. Zakres obowiązku uzyskania koncesji określa art. 21 ust. 1 pr.g.g. Dalsze szczegóły z tym związane trzeba pominąć.

${ }^{22}$ Przepis art. 12 ust. 1 pkt 2 pr.g.g. stanowi, że zarządy województw wykonują uprawnienia Skarbu Państwa wynikające z własności górniczej, w odniesieniu do działalności „o której mowa w art. 2 ust. 1". Chodzi zatem o działalność, do której przepisy Prawa geologicznego i górniczego stosuje się tylko odpowiednio.

${ }^{23}$ Stosownie do treści art. 212 ust. 3 pr.wodn. wody stanowiące własność Skarbu Państwa lub jednostek samorządu terytorialnego są wodami publicznymi.

${ }^{24}$ Stosownie do treści art. 239 ust. 1 pr.wodn. Wody Polskie są państwową osobą prawną w rozumieniu art. 9 pkt 14 ustawy z dnia 27 sierpnia 2009 r. o finansach publicznych. Z art. 239 ust. 3 pr.wodn. wynika, że w skład Wód Polskich wchodzą: Krajowy Zarząd Gospodarki Wodnej z siedzibą w Warszawie, regionalne zarządy gospodarki wodnej z siedzibami w Białymstoku, Bydgoszczy, Gdańsku, Gliwicach, Krakowie, Lublinie, Poznaniu, Rzeszowie, Szczecinie, Warszawie i we Wrocławiu, zarządy zlewni oraz nadzory wodne.

${ }^{25}$ Swego rodzaju „potwierdzenie” tej reguły wynika z art. 258 ust. 1 pr.wodn. stanowiącego, że Wody Polskie reprezentują Skarb Państwa oraz wykonują prawa właścicielskie Skarbu Państwa w stosunku do wód, o których mowa w art. 212 ust. 1 pkt 1, oraz do gruntów pokrytych śródlądowymi wodami płynącymi. Tego rodzaju „potwierdzeń” napotkać można znacznie więcej, np. z art. 263 ust. 3 pr.wodn. wynika, że uprawnienia właściciela wód w zakresie rybactwa śródlądowego w stosunku do śródlądowych wód płynących stanowiących własność Skarbu Państwa wykonują Wody Polskie.

${ }^{26}$ Aktualnie jest nim Minister Gospodarki Morskiej i Żeglugi Śródlądowej — por. rozporządzenie Rady Ministrów z dnia 7 grudnia 2015 r. w sprawie utworzenia Ministerstwa Gospodarki Morskiej i Żeglugi Śródlądowej (Dz.U. 2015, poz. 2078 ze zm.), rozporządzenie Prezesa Rady Ministrów z dnia 18 listopada 2019 r. w sprawie szczegółowego zakresu działania Ministra Gospodarki Morskiej i Żeglugi Śródlądowej (Dz.U. 2019, poz. 2262). 
morskich wód wewnętrznych), albo wreszcie minister właściwy do spraw żeglugi śródlądowej ${ }^{27}$ (w stosunku do śródlądowych dróg wodnych o szczególnym znaczeniu transportowym). Prawa właścicielskie Skarbu Państwa w stosunku do wód, o których mowa w art. 214, znajdujących się na terenie nieruchomości stanowiącej własność Skarbu Państwa, wykonują natomiast — zgodnie z treścią art. 215 ust. 1 pr.wodn. - podmioty reprezentujące Skarb Państwa w stosunku do tych nieruchomości na podstawie przepisów odrębnych ${ }^{28}$. Dla pełnego obrazu zagadnienia odnotować trzeba, że w przypadku, gdy własność wód, o których mowa w art. 214 pr.wodn., przysługuje podmiotom innym aniżeli Skarb Państwa, wówczas - co oczywiste - w obrocie prawnym podmioty te działają albo osobiście bądź przez swoje organy, albo też są reprezentowane przez przedstawicieli ustawowych bądź pełnomocników.

15. Próbując ustalić treść własności górniczej oraz własności wód, dostrzec trzeba zasadnicze różnice $\mathrm{w}$ zastosowanej przez ustawodawcę konstrukcji prawnej. Co prawda wydaje się bowiem nie budzić wątpliwości, że w obu przypadkach chodzi o prawa majątkowe o charakterze cywilnym (ze znaczną ingerencją norm prawa publicznego $)^{29}$, jednak sposób, w jaki treść tych praw została ukształtowana normatywnie, jest zdecydowanie różny. I tak treść własności górniczej określona została w art. 12 ust. 1 pr.g.g. stanowiącym, że w granicach określonych przez ustawy Skarb Państwa, z wyłączeniem innych osób, może korzystać z przedmiotu własności górniczej albo rozporządzać swoim prawem wyłącznie przez ustanowienie użytkowania górniczego. Nietrudno dostrzec, że przepis ten wyraźnie nawiązuje do modelu zastosowanego w art. 140 k.c. w odniesieniu do własności rzeczy. Wyznacza on bowiem sferę uprawnień zarówno w sposób „,negatywny” (określając granice, w jakich normowane prawo musi się mieścić), jak i „pozytywny”, wskazując atrybuty w postaci uprawnień do korzystania z przedmiotu własności oraz do rozporządzania prawem.

${ }^{27}$ Por. przypis 26.

${ }^{28}$ W tym kontekście wskazać należy na art. 11 ust. 1 ustawy z dnia 21 sierpnia 1997 r. o gospodarce nieruchomościami (t.j. Dz.U. 2020, poz. 65 ze zm.) stanowiący, że z zastrzeżeniem wyjątków wynikających z przepisów tej ustawy oraz odrębnych ustaw, organem reprezentującym Skarb Państwa w sprawach gospodarowania nieruchomościami jest starosta, wykonujący zadanie z zakresu administracji rządowej.

${ }^{29}$ O czym świadczy chociażby zastosowana zarówno w Prawie geologicznym i górniczym, jak i Prawie wodnym terminologia, gdyż w obu aktach wielokrotnie użyto nie tylko słowa „własność”, ale także np. zwrotu „uprawnienia właścicielskie”. Na cywilnoprawny charakter obydwu praw wskazują także argumenty płynące ze sposobu zredagowania wielu innych przepisów. Wystarczy tytułem przykładu przywołać art. 211 ust. 4 pr.wodn. stanowiący, że śródlądowe wody płynące będące wodami publicznymi nie podlegają obrotowi cywilnoprawnemu, z wyjątkiem przypadków określonych w ustawie. 
16. Zupełnie inaczej ustawodawca potraktował kwestię treści prawa własności wód. Próżno bowiem w Prawie wodnym poszukiwać przepisu, który mógłby zostać potraktowany jako odpowiednik przywołanego wyżej art. 12 ust. 1 pr.g.g., czy też art. 140 k.c. Ustalenie treści prawa własności wód nadal ${ }^{30}$ wymaga zatem sięgnięcia do różnych cząstkowych rozwiązań, a następnie podjęcia próby syntetyzacji uzyskanych konkluzji. Rozwijając ten wątek, w punkcie wyjścia przyjąć trzeba niekwestionowalne założenie, że w przypadku, gdy mamy do czynienia $\mathrm{z}$ własnością, to $\mathrm{w}$ rachubę wchodzi prawo, którego treścią objęte zostały dwa atrybuty, a mianowicie korzystanie $z$ dobra będącego jej przedmiotem oraz rozporządzanie tym dobrem. Wniosek taki płynie bowiem zarówno z regulacji dotyczącej własności rzeczy, jak i własności górniczej. W Prawie wodnym regulacja dotycząca korzystania z wód jest, tradycyjnie, niezwykle rozbudowana. Co do zasady nie powinno zatem budzić wątpliwości, że właściciel wody może $\mathrm{z}$ niej korzystać, jednak tylko - co oczywiste - w granicach określonych prawem, w tym zwłaszcza Prawem wodnym. Wniosek taki potwierdza chociażby treść art. 263 ust. 1 pr.wodn., z którego wynika, że ryby oraz inne organizmy żyjące $\mathrm{w}$ wodzie stanowią jej pożytki, do pobierania których jest uprawniony właściciel wód. Jest bowiem poza sporem, że pobieranie pożytków stanowi jedną z postaci korzystania, o czym przekonuje w szczególności treść art. 140 k.c.

17. Regulacja dotycząca korzystania z wód jest jednak dużo bardziej złożona. W poprzednim stanie prawnym, a także we wcześniej obowiązujących przepisach prawa wodnego, niejako tradycyjnie wyróżniano korzystanie powszechne, zwykłe i szczególne. W aktualnie obowiązującej ustawie pojawiła się natomiast - w zasadzie nieznana dotąd - forma korzystania w postaci usług wodnych ${ }^{31}$. Stosownie do treści art. 35 ust. 1 pr.wodn. usługi te polegają na zapewnieniu gospodarstwom domowym, podmiotom publicznym oraz podmiotom prowadzącym działalność gospodarczą możliwości korzystania $\mathrm{z}$ wód poza zakresem powszechnego korzystania z wód, w zakresie zwykłego korzystania z wód oraz szczególnego korzystania z wód. Nie ulega zatem wątpliwości, że jest to czwarty, wcześniej nieznany prawu wodnemu, rodzaj korzystania z wód ${ }^{32}$.

${ }^{30} \mathrm{~W}$ poprzednio obowiązującym Prawie wodnym (ustawa z dnia 18 lipca 2001 r., ostatni t.j. Dz.U. 2017, poz. 1121), a także we wcześniejszych aktach regulujących tę materię, również brak było przepisu, który wprost określał treść prawa własności wód.

${ }^{31} \mathrm{~W}$ poprzednio obowiązującym Prawie wodnym pojawiło się pojęcie usług wodnych (art. 113b ust. 7 zawierał nawet swego rodzaju definicję tych usług), jednak regulacja ta odnosiła się wprost do jednego z instrumentów w planowaniu w gospodarowaniu wodami, a mianowicie do programu wodno-środowiskowego kraju.

32 Tak też B. Rakoczy: Prawo wodne. Praktyczny przewodnik. Warszawa 2018, s. 58. Regulacja ta budzi wiele zasadniczych wątpliwości, których szczegółowa analiza wymaga jednak odrębnego opracowania. 
18. Nawet pobieżna analiza obowiązującego stanu prawnego wskazuje, że zakres korzystania z wód zależy od ich rodzaju i statusu podmiotu korzystającego. Próbując syntetycznie przedstawić ten problem, odnotować trzeba, że w odniesieniu do poszczególnych rodzajów korzystania zastosowana została nieco odmienna konstrukcja prawna. I tak w przypadku korzystania powszechnego ${ }^{33}$ chodzi w zasadzie wyłącznie o wody Skarbu Państwa ${ }^{34}$. Podkreślić należy przy tym, co w tym miejscu wydaje się szczególnie istotne, że podmiot korzystający z wód w sposób powszechny nie korzysta z przedmiotu swojej własności, ale z dobra cudzego. Inaczej omawiany problem kształtuje się przy korzystaniu zwykłym. Zgodnie $\mathrm{z}$ art. 33 ust. 1 pr.wodn. właścicielowi gruntu przysługuje bowiem prawo do zwykłego korzystania $\mathrm{z}$ wód ${ }^{35}$ stanowiących jego własność oraz $\mathrm{z}$ wód podziemnych znajdujących się w jego gruncie. Wspomniany właściciel nieruchomości może zatem korzystać w ramach przepisu z dwóch kategorii wód, co wskazuje, że konstrukcja zwykłego korzystania jest wewnętrznie zróżnicowana, obejmując zarówno korzystanie z dobra własnego, jak i cudzego (Skarbu Państwa). W odniesieniu do pierwszego z tych przypadków mamy zatem do czynienia $\mathrm{z}$ uprawnieniem niewłaściciela wynikającym $\mathrm{z}$ przepisu ustawowego, $\mathrm{w}$ drugim $-\mathrm{z}$ wyznaczeniem granic prawa własności wód. Podobnie problem kształtuje się w przypadku szczególnego korzystania $\mathrm{z}$ wód ${ }^{36}$. Nawet pobieżny ogląd przypadków, kiedy w rachubę wchodzi szczególne korzystanie $\mathrm{z}$ wód, wskazuje bowiem, że ten rodzaj korzystania obejmować może zarówno korzystanie z wody własnej, jak i Skarbu Państwa. Analogiczny wniosek przyjąć trzeba w odniesieniu do usług wodnych. Szczegóły w tym zakresie trzeba jednak pominąć.

${ }^{33}$ Stosownie do treści art. 32 ust. 1 pr.wodn. każdemu przysługuje prawo do powszechnego korzystania z publicznych śródlądowych wód powierzchniowych, morskich wód wewnętrznych oraz z wód morza terytorialnego, jeżeli przepisy ustawy nie stanowią inaczej. Korzystanie to służy do zaspokajania potrzeb osobistych, gospodarstwa domowego lub rolnego, bez stosowania specjalnych urządzeń technicznych, a także do wypoczynku, uprawiania turystyki, sportów wodnych oraz, na zasadach określonych w przepisach odrębnych, amatorskiego połowu ryb (art. 32 ust. 2 pr.wodn.).

${ }^{34}$ Zgodnie jednak z art. 32 ust. 3 pr.wodn. rada gminy może wprowadzić, w drodze uchwały będącej aktem prawa miejscowego, powszechne korzystanie $\mathrm{z}$ wód powierzchniowych nie będących własnością Skarbu Państwa, służące zaspokajaniu wyłącznie potrzeb osobistych, gospodarstwa domowego lub rolnego i ustalić dopuszczalny zakres tego korzystania. W takim przypadku, właścicielowi wód przysługuje odszkodowanie z budżetu gminy (art. 32 ust. 4 pr.wodn.).

${ }^{35} \mathrm{~W}$ myśl art. 33 ust. 3 pr.wodn. zwykłe korzystanie z wód służy zaspokojeniu potrzeb własnego gospodarstwa domowego oraz gospodarstwa rolnego. Nie obejmuje ono jednak poboru wód podziemnych lub wód powierzchniowych w ilości średniorocznie nieprzekraczającej $5 \mathrm{~m}^{3}$ na dobę oraz wprowadzania ścieków do wód lub do ziemi w ilości nieprzekraczającej łącznie $5 \mathrm{~m}^{3}$ na dobę.

${ }^{36}$ Stosownie do treści art. 34 ust. 1 pr.wodn. szczególnym korzystaniem z wód jest korzystanie $\mathrm{z}$ nich w zakresie wykraczającym poza powszechne korzystanie oraz zwykłe korzystanie $\mathrm{z}$ wód. W dalszej części w przepisie tym wymieniono zamkniętą listę 16 rodzajów szczególnego korzystania z wód. 
19. Generalna konkluzja odniesiona do ostatnio rozpatrywanej problematyki sprowadza się do konstatacji, że w przypadku regulacji dotyczącej korzystania z wód nacisk położony został przede wszystkim na aspekt „reglamentacyjny”. W zakresie dotyczącym korzystania powszechnego i zwykłego granice korzystania wyznaczone zostały aktem generalnym, albowiem to ustawa określa komu, $\mathrm{z}$ jakich wód i dla zaspokojenia jakich potrzeb wolno korzystać. W przypadku dotyczącym korzystania szczególnego i usług wodnych, wyznaczenie wspomnianych granic dokonywane jest (może być) za pomocą aktu indywidualnego. Przepisy regulujące korzystanie $\mathrm{z}$ wód zostały natomiast tak skonstruowane, że nie wskazują tytułu prawnego do korzystania. Sprawia to, że zwłaszcza charakter praw przysługujących oznaczonym podmiotom w stosunku do cudzych wód w ramach każdego ze sposobów korzystania $\mathrm{z}$ wód budzić może wątpliwości. $\mathrm{Z}$ dotychczasowych uwag dotyczących rodzajów korzystania $\mathrm{z}$ wód wynika jednak ponad wszelką wątpliwość, że uprawnienia w tym zakresie przysługiwać mogą zarówno właścicielowi wód, jak i podmiotom, które nie posiadają takiego statusu. W odniesieniu do tych pierwszych $\mathrm{w}$ rachubę wchodzi zatem atrybut korzystania ze swojego prawa.

20. Jeśli chodzi z kolei o atrybut rozporządzania, to - podobnie jak w przypadku korzystania - konstrukcja dotycząca własności górniczej odbiega znacząco od tej, która przyjęta została w odniesieniu do wód. W przywołanym już art. 12 ust. 1 pr.g.g. przesądzono, że jedyną formą rozporządzenia własnością górniczą jest ustanowienie użytkowania górniczego ${ }^{37}$. De lege lata wykluczone jest zatem zarówno zbycie tej własności, jak również obciążenie jej prawami innymi aniżeli wspomniane użytkowanie. W przypadku Prawa wodnego regulacja dotycząca rozporządzania jest natomiast mocno fragmentaryczna. Najbardziej generalny charakter w rozpatrywanym zakresie wydaje się mieć art. 211 ust. 4 pr.wodn., stanowiący, że śródlądowe wody płynące będące wodami publicznymi nie podlegają obrotowi cywilnoprawnemu, z wyjątkiem przypadków określonych w ustawie. Nie można też tracić z pola widzenia unormowań dotyczących oddawania w użytkowanie obwodów rybackich. Pod rządem Prawa wodnego z $2001 \mathrm{r}$. materia ta uregulowana była w tym akcie normatywnym.

37 Stosownie do art. 13 ust. 1 pr.g.g. ustanowienie użytkowania górniczego następuje w drodze umowy zawartej na piśmie pod rygorem nieważności. Treść tego przepisu jest kolejnym argumentem na rzecz tezy, że własność górnicza (a także prawo od niej pochodne, jakim jest użytkowanie górnicze) ma charakter cywilnoprawny. Konstatacji tej nie zmienia fakt, że zgodnie $\mathrm{z}$ art. 13 ust. 6 pr.g.g. w przypadku nieuzyskania koncesji w terminie roku od dnia zawarcia umowy o ustanowieniu użytkowania górniczego, umowa ta wygasa, w myśl zaś art. 13 ust. 7 pr.g.g. użytkowanie górnicze wygasa w przypadku wygaśnięcia, cofnięcia lub utraty mocy koncesji, bez względu na przyczynę. Gwoli ścisłości odnotować trzeba jednak, że użytkowanie górnicze ustanawiane jest także w przypadku prowadzenia niektórych rodzajów działalności nie wymagających uzyskania koncesji, szczegółów w tym zakresie niepodobna jednak rozwinąć. 
Aktualnie, zgodnie z treścią art. 263 ust. 4 pr.wodn., zasady i warunki rybackiego korzystania z publicznych śródlądowych wód płynących są określone w przepisach ustawy z dnia 18 kwietnia 1985 r. o rybactwie śródlądowym ${ }^{38}$. Omawianą materię normuje przede wszystkim art. 6d ustawy, z którego ust. 1 wynika, że publiczne śródlądowe wody powierzchniowe płynące stanowiące własność Skarbu Państwa dyrektor regionalnego zarządu Państwowego Gospodarstwa Wodnego Wody Polskie przekazuje do rybackiego korzystania w drodze oddania w użytkowanie obwodu rybackiego. Formą rozporządzenia tymi wodami jest zatem ustanowienie użytkowania. Oddanie w użytkowanie obwodu rybackiego następuje w drodze konkursu ofert (art. 6d ust. 4 ustawy), co oznacza, że $\mathrm{w}$ istocie rzeczy chodzi o wyłonienie użytkownika w drodze przetargu. Przepisy omawianej ustawy nie określają wprost, że oddanie w użytkowanie rybackie następuje w drodze umowy, jednak o tym, że tak jest, pośrednio przekonuje treść jej art. 6d ust. 6, w którym mowa o rozwiązaniu umowy użytkowania. Skądinąd zresztą, w myśl art. 6d ust. 7 ustawy, w sprawach nieuregulowanych dotyczących użytkowania stosuje się odpowiednio przepisy Kodeksu cywilnego.

21. Przytoczone wyżej reguły odnoszą się wprost do rozporządzania prawami do wód. Znacznie bardziej rozbudowana jest natomiast regulacja odnosząca się do rozporządzania gruntami pod wodami państwowymi, co nie pozostaje bez wpływu na możliwość korzystania z wód, a więc postrzegane może być jako czynności ze skutkiem „rozporządzającym” w odniesieniu do wód ${ }^{39}$. Odmienne reguły od dotychczas przedstawionych dotyczą natomiast rozporządzania wodami niepublicznymi. Wydaje się bowiem, że właściciel tych wód może nimi rozporządzić także w inny sposób. Może to przybrać postać zarówno obciążenia własności wód oznaczonym prawem osoby trzeciej (np. umownego ustanowienia prawa czerpania wody czy też prawa przejazdu [,„przepływu”] przez powierzchniowe wody stojące), jak również przeniesienia ich własności. Aktualnie obowiązujące Prawo wodne nie zawiera odpowiednika art. 12 poprzednio obowiązującej ustawy, który stanowił, że własność wód stojących oraz wód $\mathrm{w}$ studniach $\mathrm{i} \mathrm{w}$ rowach jest prawem związanym $\mathrm{z}$ własnością nieruchomości gruntowej. A skoro tak, to wydaje się, że de lege lata nie została wykluczona możliwość przeniesienia na oznaczony podmiot własności wody bez równoczesnego przeniesienia własności gruntu. Nie mogłoby to jednak nastąpić w sposób naruszający zasadę wyrażoną w art. 214 pr.wodn. Zbycie wody byłoby zatem możliwe jedynie wówczas, gdy została by ona oddzielona od gruntu,

38 Dz.U. 2019, poz. 2168 ze zm.

39 Jeśli bowiem zgodnie z treścią art. 261 ust. 1 pr.wodn. grunty pokryte wodami stanowiące własność Skarbu Państwa, niezbędne do prowadzenia przedsięwzięć związanych np. z energetyką wodną, oddaje się w użytkowanie, to jest oczywiste, że tego rodzaju stan rzeczy oznacza także jakąś formę rozporządzenia wodami, skoro skutkiem tego jest de facto także użytkowanie wód. 
na/w którym się znajduje (np. poprzez jej wypompowanie). Przypadki takie, zapewne możliwe, będą jednak, jak się wydaje, rzadkością.

22. Na zakończenie rozważyć trzeba wreszcie pokrótce kwestię ochrony obydwu analizowanych praw, podkreślając już w punkcie wyjścia, że jest to materia różniąca się od problematyki ochrony kopalin czy wód jako elementów środowiska. Także i w tym zakresie regulacja zawarta w Prawie geologicznym i górniczym znacząco różni się od tej, która zamieszczona została w Prawie wodnym. $\mathrm{Z}$ art. 11 pr.g.g. wynika bowiem, że w sprawach nieuregulowanych w ustawie do własności górniczej, a także do rozstrzygania sporów między Skarbem Państwa a właścicielem gruntu, stosuje się odpowiednio przepisy Kodeksu cywilnego, a także prawa geodezyjnego i kartograficznego ${ }^{40}$ dotyczące nieruchomości gruntowych, w tym ich rozgraniczania. Nie ulega zatem wątpliwości, że odesłanie to obejmuje m.in. art. 222 k.c. normujący ochronę petytoryjną prawa własności. Właścicielowi górniczemu służy zatem zarówno roszczenie windykacyjne ${ }^{41}$ (gdy Skarb Państwa pozbawiony zostanie władztwa nad przedmiotem własności górniczej), jak i negatoryjne ${ }^{42}$ (gdy w rachubę wejdą innego rodzaju naruszenia nie polegające na pozbawieniu uprawnionego władztwa nad swoim dobrem).

23. Cywilnoprawna ochrona prawa własności przysługującego w odniesieniu do wód nie doczekała się, podobnie jak w poprzednim Prawie wodnym z 2001 r., jakiejkolwiek regulacji, z której wynikałaby odpowiedź na pytanie o jej zakres i instrumenty prawne mogące służyć temu celowi. Podtrzymać należy zatem od dawna głoszony pogląd ${ }^{43}$, że brak alternatywy dla rozwiązania przyjmującego, iż w zakresie nienormowanym prawem wodnym stosować należy przepisy Kodeksu cywilnego dotyczące własności nieruchomości. Odrzucenie tego poglądu powodowałoby bowiem, że w pewnym zakresie sfera uprawnień właściciela wody pozostawałaby całkowicie niechroniona. Niepodobna zaś przyjąć, że wspomnianym podmiotom nie służą żadne cywilnoprawne środki ochrony prawa własności wody. A skoro tak, to jedynym rozwiązaniem wydaje się dopuszczenie możliwości skorzystania w rozpatrywanym przypadku

${ }^{40}$ Ustawa z dnia 17 maja 1989 r. - Prawo geodezyjne i kartograficzne (Dz.U. 2020, poz. $276 \mathrm{ze} \mathrm{zm}$.).

${ }^{41}$ Stosownie do art. $222 \S 1$ k.c. właściciel może żądać od osoby, która włada faktycznie jego rzeczą, ażeby rzecz została mu wydana, chyba że osobie tej przysługuje skuteczne względem właściciela uprawnienie do władania rzeczą.

${ }^{42} \mathrm{~W}$ myśl art. $222 \S 2$ k.c. przeciwko osobie, która narusza własność w inny sposób aniżeli przez pozbawienie właściciela faktycznego władztwa nad rzeczą, przysługuje właścicielowi roszczenie o przywrócenie stanu zgodnego z prawem i o zaniechanie naruszeń.

${ }^{43}$ Por. R. Mikosz. W: System Prawa Prywatnego. T. 4. Red. E. Gniewek. Prawo rzeczowe. Warszawa 2005, s. 698-699. 
z roszczeń zarówno petytoryjnych, jak i z ochrony posesoryjnej. Oznacza to, innymi słowy, że dopuścić trzeba stosowanie w tym zakresie regulacji zawartej w art. 222 oraz 343 i 344 k.c. Właściciel wód może zatem, w przypadku pozbawienia go władztwa nad wodą będącą przedmiotem jego własności sięgnąc do roszczenia windykacyjnego, a w przypadku innych naruszeń jego prawa do roszczenia negatoryjnego. Może również stosować środki prawne służące ochronie posiadania.

24. Z dotychczasowych spostrzeżeń dowodnie wynika, że konstrukcja prawna własności geologicznych zasobów skorupy ziemskiej (własności górniczej) w istotny sposób różni się od tej, którą przyjęto w stosunku do wód. Trudno dociec przyczyn takiego zróżnicowania, zwłaszcza gdy zważyć, że przedmiotem własności są $\mathrm{w}$ obu rozpatrywanych przypadkach dobra o porównywalnym statusie, będące według dość powszechnie przyjmowanego poglądu przedmiotami materialnymi nie mającymi statusu rzeczy w rozumieniu art. 45 k.c., a także znaczącymi elementami środowiska.

Wydaje się, że bezsprzecznie lepszym rozwiązaniem jest to, które zastosowane zostało w odniesieniu do własności górniczej, gdyż zasadnie nawiązuje ono do modelu regulacji prawnej dotyczącej własności rzeczy. Nie oznacza to jednak, że rozwiązanie to nie budzi żadnych wątpliwości ${ }^{44}$. Są one jednak zdecydowanie mniejsze aniżeli te, które dotyczą regulacji prawnej odnoszącej się do własności wód. Jest ona bowiem mocno niekompletna, nadto zaś rozproszona i — co nietrudno dostrzec — pozbawiona wyraźniejszej myśli przewodniej. Tymczasem zaś jeśli w tekście ustawy wielokrotnie użyto w stosunku do wód słowa „własność”, to bezspornie mamy do czynienia z cywilnym majątkowym prawem podmiotowym, co rodzi określone konsekwencje. W takim przypadku zatem trzeba klarownie wskazać nie tylko jej podmiot (podmioty) i przedmiot, ale także - co najmniej - określić również treść tego prawa oraz środki jego ochrony. Wszystkiego tego próżno szukać w ustawie Prawo wodne mimo jej olbrzymich rozmiarów ${ }^{45}$.

${ }^{44}$ Por. R. Mıkosz: Kilka uwag o wzajemnych relacjach między własnościa górnicza a własnościa gruntowa. W: Rozprawy z prawa prywatnego. Księga pamiatkowa dedykowana Profesorowi Wojciechowi Popiołkowi. Red. M. Pazdan, M. Jagielska, M. Rott-Pietrzyk, M. SzPUNAR. Warszawa 2017, s. 1193 i nast.

${ }^{45} \mathrm{Z}$ art. 1 pr.wodn. wynika, że ustawa reguluje gospodarowanie wodami zgodnie z zasadą zrównoważonego rozwoju, w szczególności kształtowanie i ochronę zasobów wodnych, korzystanie $\mathrm{z}$ wód oraz zarządzanie zasobami wodnymi. Przepis art. 2 pr.wodn. stanowi natomiast, że ustawa reguluje sprawy własności wód oraz gruntów pokrytych wodami, a także zasady gospodarowania tymi składnikami jako mieniem Skarbu Państwa. Tytułem porównania, art. 1 poprzednio obowiązującego Prawa wodnego (por. przypis 30) stanowił, że reguluje ono gospodarowanie wodami zgodnie z zasadą zrównoważonego rozwoju, a w szczególności kształtowanie i ochronę zasobów wodnych, korzystanie $\mathrm{z}$ wód oraz zarządzanie zasobami wodnymi. $\mathrm{Z}$ art. 1a. wynikało natomiast, że ustawa reguluje sprawy własności wód oraz gruntów pokrytych wodami, 


\section{Literatura}

Kilka uwag o wzajemnych relacjach między własnościa górnicza a własnościa gruntową. W: Rozprawy z prawa prywatnego. Ksiega pamiattowa dedykowana Profesorowi Wojciechowi Popiołkowi. Red. M. Pazdan, M. Jagielska, M. Rott-PietrzyK, M. Szpunar. Warszawa 2017.

KLEIN A.: Elementy stosunku prawnego prawa rzeczowego. Wrocław 1976.

LipiŃSKi A.: Komentarz do art. 6-9 ustawy z dnia 9 czerwca 2011 r. Prawo geologiczne i górnicze. „Problemy Prawne Górnictwa i Ochrony Środowiska” 2017, nr 1, s. 11-31.

Lipiński A.: Prawne podstawy geologii i górnictwa. Warszawa 2019.

Lipiński R., Mikosz A.: Prawo geologiczne i górnicze. Komentarz. Warszawa 2003.

Mikosz R.: Własność górnicza - ewolucja stanu prawnego. W: Rozważania o... Red. G. DoBROWOLSKI. Katowice 2018.

PaŃko W.: Własność gruntowa w planowej gospodarce przestrzennej. Katowice 1978.

Rakoczy B.: Prawo wodne. Praktyczny przewodnik. Warszawa 2018.

System Prawa Prywatnego. T. 3: Prawo rzeczowe. Red. E. Gniewek. Wyd. 4. Warszawa 2020.

System Prawa Prywatnego. T. 4: Prawo rzeczowe. Red. E. GnieweK. Warszawa 2005.

Wojtulek P., Kocowski T., MaŁecki W.: Prawo geologiczne i górnicze. Warszawa 2020.

Ryszard Mikosz

\section{Ownership of minerals and water ownership - a few remarks about the legal structure}

Summary

The subject of the considerations contained in the article is the analysis of the legal structure used in the Act of 9 June 2011 in relation to the ownership of minerals and in the Act of 20 July 2017 on Water Law in relation to waters. This analysis covered the determination of the subject of ownership, right holders, the content of ownership and protection instruments of the owner. It showed a lot of significant shortcomings in legal regulation, especially that concerning water properties. This regulation is in fact incomplete, and, moreover, dispersed and devoid of a clearer idea.

Key words: Ownership of mineral deposits, mining property, water ownership, use of water

a także zasady gospodarowania tymi składnikami w odniesieniu do majątku Skarbu Państwa. Nie sposób dociec, co takiego się wydarzyło w ciągu 16 lat, że przy tym samym zakresie przedmiotowym ustawy uznano za konieczne dodanie do dotychczasowych 220 artykułów kolejnych 354. 
Рышард Микош

\section{Право собственности на полезные ископаемые и водные объекты - некоторые замечания о правовой структуре}

Резюме

Предметом размышлений, содержащихся в статье, является анализ правовой структуры, используемой в Законе о праве собственности на месторождения полезных ископаемых от 9 июня 2011 г., а также в Водном кодексе от 20 июля 2017 г. в отношении водных ресурсов. Этот анализ включал определение предмета собственности, уполномоченных субъектов, содержание собственности и средств защиты, полагающихся владельцу. Он показал много существенных недостатков в правовом регулировании, особенно в том, что касается право собственности на водные объекты. Это правовое регулирование является неполным, кроме того, оно разрознено и лишено более ясной основной мысли.

Ключевые слова: право собственности на месторождения полезных ископаемых, право собственности на недра, право собственности на водные объекты, водопользование

Ryszard Mikosz

\section{Proprietà di minerali e d'acqua - alcuni commenti sulla costruzione legale}

\section{Sommario}

Oggetto delle considerazioni contenute nell' articolo è l'analisi della struttura giuridica utilizzata nella legge del 9 giugno 2011 in relazione alla proprietà dei minerali e nella legge del 20 luglio 2017. Legge sull'acqua in relazione alle acque. Quest'analisi ha compreso la determinazione dell'oggetto di proprietà, delle entita' autorizzate, del contenuto di proprietà e degli strumenti di protezione dovuti al proprietario. L'analisi ha evidenziato una serie di carenze significative nella regolamentazione giuridica, in particolare quella relativa alla proprietà delle acque. Questo regolamento è molto incompleto e, inoltre, è disperso e privo di una chiara idea guida.

Parole chiave: Proprietà dei giacimenti minerali, proprietà minerarie, proprietà dell'acqua, uso dell'acqua 